\title{
La Fanciulla del West de Giacomo Puccin: A(s) Química(s) DE UMa Ópera
}

\author{
João Paulo André \\ Departamento/Centro de Química, Universidade do Minho - Braga \\ jandre@quimica.uminho.pt
}

\begin{abstract}
Giacomo Puccini's La Fanciulla del West: A Chemical View of an Opera - La Fanciulla del West, the exciting opera of Giacomo Puccini which premiered at the MET (The Metropolitan Opera House) in New York in 1910, sets a scene with many interwoven stories providing a great variety of topics to be discussed. This opera has therefore an exceptional pedagogical potential.

The present paper analyzes and discusses the "chemical content" of La Fanciulla, including references to other works where appropriate. The analysis of the opera's chemical ingredients reveals gold, ethanol, nicotine, and, above all, a lot of nitric oxide. This gas, despite being absolutely essential for the plot of La Fanciulla, is not, however, an exclusive ingredient of this opera. In fact, its small diatomic molecule happens to trigger the actions of a large number of operatic stories... and of many stories of mankind.
\end{abstract}

La Fanciulla del West, a excitante ópera de Giacomo Puccini estreada em 1910 no MET (The Metropolitan Opera House), em Nova Iorque, é uma história de muitas histórias que proporciona a discussão de uma alargada variedade de temas. É, assim, uma ópera com um elevado potencial pedagógico.

Neste artigo analisa-se e discute-se o "conteúdo químico" de La Fanciulla, fazendo-se, sempre que oportuno, referência a outras obras. A análise efectuada revela ouro, etanol, nicotina e, acima de tudo, muito óxido nítrico. Este último é um gás que, apesar de se revelar absolutamente fundamental na trama de La Fanciulla, não é, todavia, um ingrediente exclusivo desta ópera. Com efeito, a sua pequena molécula diatómica actua como "gatilho" da aç̧ão de uma grande parte das histórias operáticas... e de muitas histórias da Humanidade.

"In those strange days, people coming from God knows where, joined forces in that far Western land, and, according to the rude custom of the camp, their very names were soon lost and unrecorded, and here they struggled, laughed, gambled, cursed, killed, loved and worked out their strange destinies in a manner incredible to us of today. Of one thing only are we sure - they lived!"

"Early History of California”, in D. Belasco, The Girl of the Golden West [1]

\section{INTRODUÇÃO}

Se por breves instantes, à escala de tempo da nossa História, o Homem teve o sonho alquímico de obter ouro a partir de metais inferiores, logo reconheceu, resignadamente, que nada mais lhe restava senão extraí-lo das entranhas da Terra. Dessas andanças garimpeiras, perpetuadas ao longo dos séculos, a "Febre do Ouro" (Gold Rush) da Califórnia, ocorrida entre 1848 e 1855, será porventura a mais célebre. Tudo começou quando James W. Marshall encontrou o "vil metal” ao construir uma serração junto ao Rio Americano, na Califórnia. Johann Sutter, proprietário do terreno e um dos pioneiros da conquista daquela província dos EUA, acabaria por ver o seu negócio de madeiras e de exploração agrícola ruírem no seguimento da agitação gerada pelo achado, sem, em compensação, ter tirado proveito do ouro [2].

Foi neste ambiente de grande efervescência, em que milhares de homens rumavam ao Oeste bravio em busca do metal amarelo, que o dramaturgo norte-americano David Belasco (1853-1931) - um judeu de ascendência portuguesa - localizou a acção da peça The Girl of the Golden West, estreada em Nova Iorque em 1905 (Figura 1). Giacomo
Puccini (1858-1924) viu-a dois anos mais tarde, aquando de uma visita à cidade. Não falando nem entendendo o inglês, ficou tão entusiasmado com o que viu em cena que quis logo fazer da peça uma ópera. Esta atracção de Puccini por obras de Belasco não era, porém, inédita: a sua ópera Madama Butterfly (1904) já tinha sido baseada numa peça do dramaturgo.

O novo projecto operático acabaria por tomar forma com um libreto da autoria de Guelfo Civinini e Carlo Zangarini, sob o título italianizado de La Fanciulla del West (em italiano, fanciulla quer dizer "rapa-

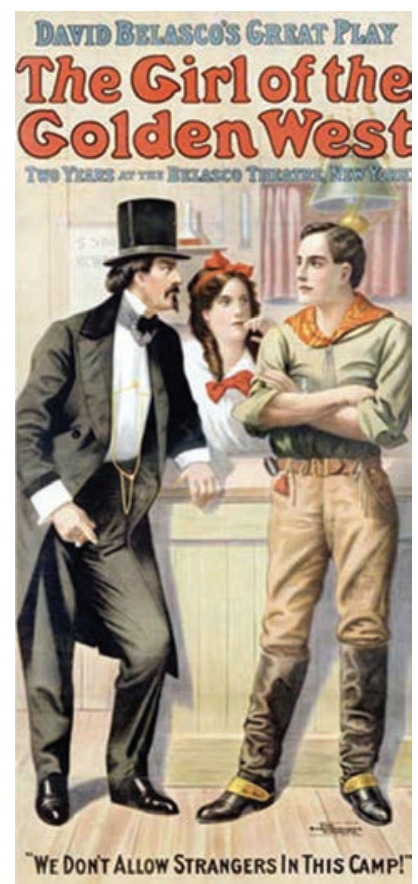

Figura 1 - Cartaz original da peça The Girl of the Golden West (1905) de David Belasco 
riguinha”). A estreia, com grande sucesso, seria três anos mais tarde no MET (The Metropolitan Opera House) de Nova Iorque, tendo contado com a direcção do lendário maestro Arturo Toscanini e com o tenor Enrico Caruso no papel masculino principal (Figura 2, à esquerda) [3,4]. Em Portugal, a ópera estreou no S. Carlos na temporada de 1954-55 (com a Maria Caniglia e o Tito Gobbi!); lamentavelmente não voltou a ser cantada por cá [5].
A história de La Fanciulla começa no dia em que Dick Johnson, aliás Ramerrez (tenor), surge no "Polka”. A paixão mútua de Minnie e Johnson é inevitável (Figura 4), apesar do impedimento de Jack Rance, o poderoso sheriff (barítono) que deseja Minnie a todo o custo. Trata-se, assim, de uma ópera que encaixa à perfeição no estereótipo definido por Bernard Shaw: "[ópera] é quando o tenor e a soprano querem fazer amor mas são impedidos de o fazer pelo barítono”.
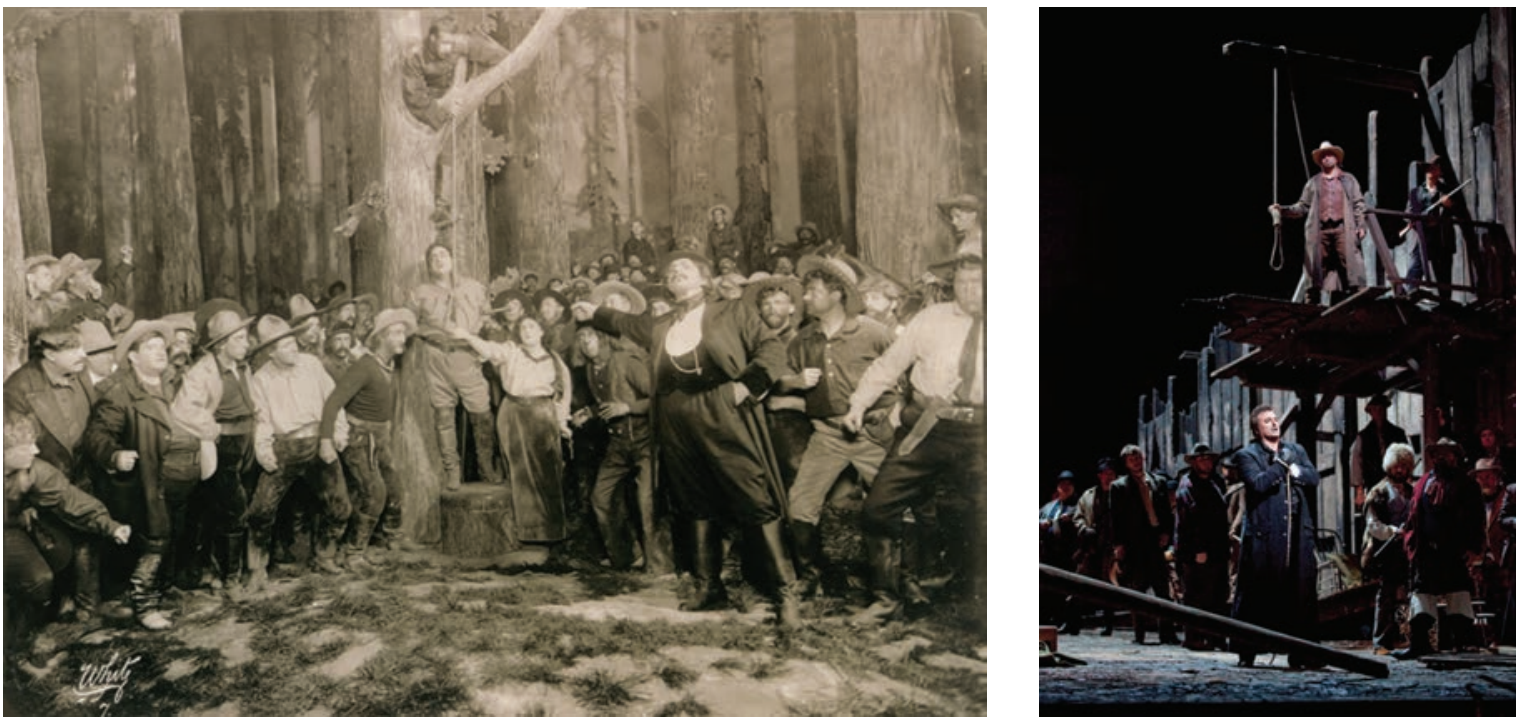

Figura 2 - La Fanciulla del West, cena final do enforcamento de Johnson em duas produções do MET separadas por cem anos (esquerda: Enrico Caruso na estreia em 1910 - ( C White Studios/The Metropolitan Opera Archives; direita: Marcello Giordani em 2010 - @ Ken Howard/Metropolitan Opera)

A acção de La Fanciulla decorre nas imediações de um acampamento de mineiros de ouro nas serras da Califórnia. Para maior “cor local”, Puccini integrou na partitura algumas melodias tradicionais norte-americanas, enquanto no libreto abundam palavras e expressões como "hello", "whisky", "Wells Fargo"1 ou algo como ''dooda dooda day". Igualmente contribuem para o efeito as referências a lugares como S. Francisco, Sacramento, Monterey e Califórnia, bem como o facto de Wowkle, a empregada de Minnie, ser "pele-vermelha”. Apesar do sucesso inicial, a ópera não deixou de ser apelidada de western spaghett ${ }^{2}$ nem nunca chegou a ser das mais populares do compositor. A música, porém, é do melhor que lhe saiu do punho.

A heroína da história é Minnie (Figura 3), dona do saloon "Polka” e uma corajosa self-made woman que não hesita, no final, em pegar no revólver e enfrentar uma multidão de homens enfurecidos para salvar o homem que ama. É no "Polka" que, ao fim do dia, saudosos de casa e mais ou menos enamorados de Minnie, os mineiros bebem "whisky" (sic) e fumam charutos. É lá também que ela lhes dá lições de catequese e lhes guarda o ouro num barril.

\footnotetext{
${ }^{1}$ Wells Fargo é o nome de um banco, ainda hoje activo, criado em 1852 por Henry Wells e William Fargo ao estabelecerem uma companhia de diligências e serviços bancários com sede em São Francisco

2 Designação dada aos filmes western de produção italiana das décadas de 60 e 70 do século passado, nos quais se destacou o realizador Sergio Leone
}

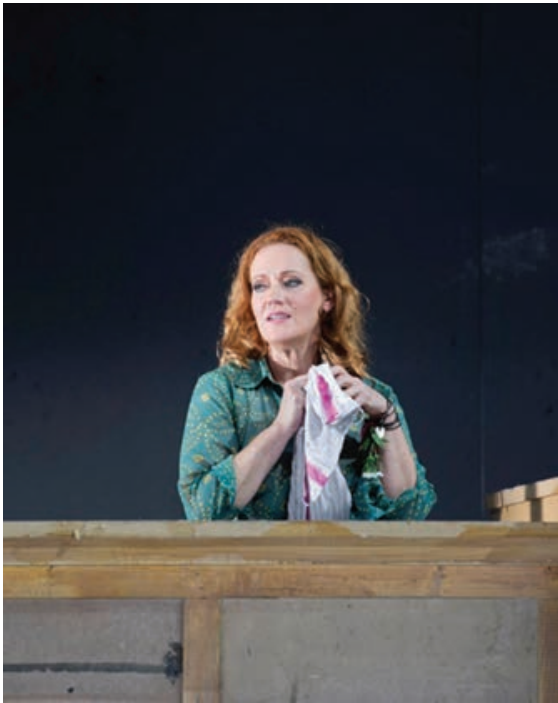

Figura 3 - Catherine Naglestad (Minnie) na Ópera de Zurique, 2014 () Monika Rittershaus/Opernhaus Zürich)

Ao longo deste texto, baseado em La Fanciulla del West, ver-se-á que as relações que se podem estabelecer entre Química e Ópera não se baseiam exclusivamente nos venenos e poções de grande parte dos enredos nem, tão pouco, nas abordagens operáticas de temas científicos como, por exemplo, em Doctor Atomic ${ }^{3}$ (John Adams) ou Madame Curie (Elżbieta Sikora) [6].

\footnotetext{
${ }^{3}$ Doctor Atomic aborda directamente a questão da bomba atómica
} 

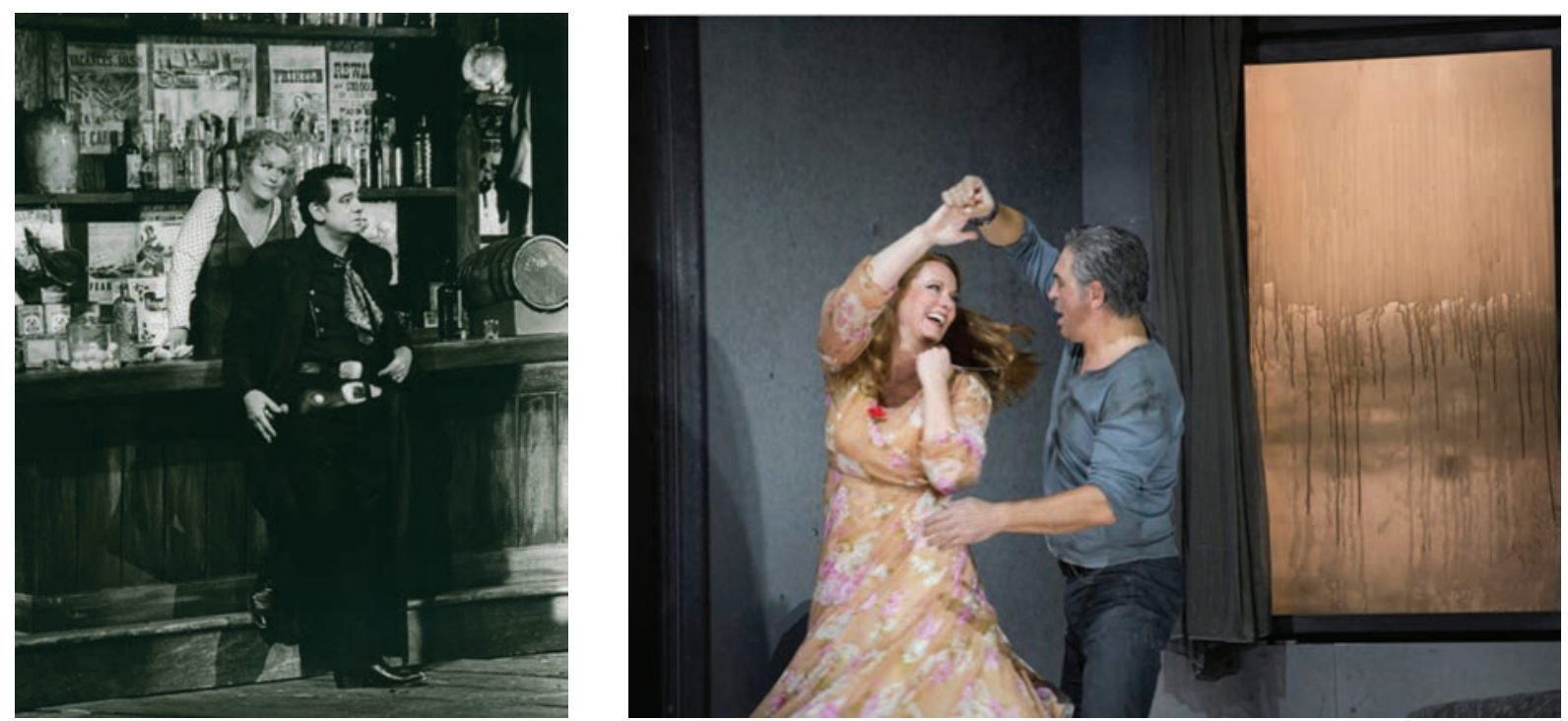

Figura 4 - Esquerda: Barbara Daniels (Minnie) e Plácido Domingo (Johnson) no MET, 1991 (@ Winnie Klotz/The Metropolitan Opera Archives); direita: Catherine Naglestad (Minnie) e Zoran Todorovich (Johnson) na Ópera de Zurique, 2014 (@ Monika Rittershaus/Opernhaus Zürich)

\section{OURO}

La Fanciulla conta-nos uma história de redenção pelo amor e, simultaneamente, do deslumbramento humano pelo ouro. Nela encontramos o retrato da vida de grande dureza física e psicológica dos mineiros da Gold Rush da Califórnia. Minnie, no I acto, descreve essa realidade quando se refere aos mineiros nos seguintes termos: " $e$ son venuti $a$ morir come cani, in mezzo alla fanghiglia, per mandare un po d'oro ai cari vecchi, ed ai bimbi lontani!" (e acabam por morrer como cães no meio da lama, tudo para enviarem um pouco de ouro aos pais queridos e aos filhos lá longe). Por sua vez, também no I acto, Rance refere-se ao Oeste "dourado" da seguinte forma: "Che terra maledetta, quest' occidente d' oro!” (Que terra maldita este ocidente de ouro!). Nick, o empregado do saloon, responde-lhe que “ $L$ ' oro avvelena il sangue a chi lo guarda" (O ouro envenena o sangue de quem o vê).

Vejamos como na célebre Histoire Naturelle de Buffon (publicada originalmente em Paris entre 1749 e 1789), o ouro é descrito: "o ferro pode sofrer transformações e tomar estados diferentes, seja por causas naturais, seja pelos efeitos da nossa arte; o ouro, todavia, apresenta-se-nos fixo, imutável e constantemente o mesmo, tanto sob a nossa mão como sob a da natureza: de todas as matérias do globo é a mais pesada, ${ }^{4}$ a mais inalterável, a mais tenaz e a mais extensível. É pela reunião destas proeminentes características que ao longo dos tempos o ouro foi visto como o metal mais perfeito e mais precioso, tendo-se tornado, por um consentimento unânime e tácito de todos os povos, o padrão universal e invariável do valor de todas as outras matérias.” [7].

De facto não são muitos os metais que aparecem na natureza na forma metálica (nativa). O ouro, detentor de uma baixíssima reactividade química, é uma das excepções (a par da prata, platina, cobre, mercúrio e bismuto [8]). O

4 O elemento de maior densidade é o ósmio; o ouro é o quinto elemento mais denso ouro surge igualmente sob a forma de ligas metálicas (sobretudo com a prata) e a sua inércia química não o impede de formar também alguns minérios, sobretudo com elementos como o telúrio, a prata e o chumbo [9]. No estado nativo, pode ser encontrado na forma de veios incrustados em quartzo (ouro primário) e ainda nos vales e areais de rios para onde foi arrastado sob a forma de fragmentos de dimensões variáveis (desde partículas microscópicas até grãos ou mesmo pepitas), libertados na sequência de processos de erosão (ouro secundário) [10].

Em tempos remotos, as areias auríferas extraídas de depósitos aluviais eram lavadas, peneiradas e posteriormente passadas por uma pele de lã ovina, cuja lanolina retinha as partículas mais pequenas de ouro. Por fim as peles eram submetidas a altas temperaturas, sendo as gotas de metal formadas, por fusão da poeira de ouro, facilmente removidas das cinzas. Este método de exploração de ouro aluvial, praticado há mais de três mil anos nas margens dos rios da região do Mar Negro, constitui a origem da lenda de Jasão e dos Argonautas - os heróis da mitologia grega que partiram em busca do Velo (Tosão) de Ouro ${ }^{5}$, que faria de Jasão rei da Tessália. Esta história de ambição teria sido muito menos interessante, e menos bem sucedida, se dela também não fizesse parte a prodigiosa Medeia [11,12]. ${ }^{6}$

Outro processo arcaico, mas ainda em uso, de extracção e purificação de ouro, sobretudo o dos depósitos aluviais, ba-

\footnotetext{
5 Na mitologia grega, o Velo de Ouro era a pele de ouro de Crisómalo, o carneiro alado

6 Na expedição na Argo à conquista do Velo de Ouro, Jasão e os Argonautas atracaram na Cólquida (actual Geórgia). Medeia, a filha do rei, perde-se de amores por Jasão e, sob condição de se casarem, recorrendo à feitiçaria ajuda-o a superar as várias provas (consideradas impossíveis) que lhe permitirão atingir o Velo de Ouro. Após a obtenção do Velo, refugiam-se em Corinto onde Jasão se enamora de Glauce, abandonando Medeia. Esta, cega de dor e de ódio, vinga-se de Jasão matando-lhe os filhos, que eram também os seus. Assim consta na tragédia Medeia (431 a.C.) de Eurípedes que, por sua vez, inspirou várias óperas, das quais se destaca Médée (1797) de Luigi Cherubini
} 
seia-se na sua amalgamação com mercúrio. Ao aquecer-se a amálgama obtida, o mercúrio evapora-se deixando atrás de si o ouro. A mina de mercúrio de New Almaden, em Santa Clara da Califórnia, viria a fornecer a partir de 1848 o metal necessário para a purificação do ouro da Gold Rush [13]. Na actualidade, a actividade dos garimpeiros de ouro na floresta da Amazónia tem sido responsável pela libertação para o ambiente de grandes quantidades de mercúrio (estima-se que por cada quilograma de ouro obtido sejam libertados 1,3 kg de mercúrio). Na bacia do rio Tapajós, no Estado do Pará, calcula-se que sejam lançados anualmente cerca de doze toneladas de mercúrio para o ar, rios e subsolo [14].

Uma das melhores metáforas do fascínio humano pelo ouro e pelo poder aparece-nos n’ O Ouro do Reno (1869), uma das quatro óperas do ciclo $O$ Anel do Nibelungo de Richard Wagner. A trama d’ O Ouro gira em torno do anel mágico forjado pelos Nibelungos a partir do ouro do rio Reno, roubado num momento de distracção das Ninfas suas guardiãs. Quem possuir o anel e renunciar ao amor dominará o Mundo. Na literatura universal, por sua vez, destaca-se o seguinte excerto da cena 3 do IV acto de Timão de Atenas de Shakespeare:

"Que vejo eu? Ouro! Amarelo e brilhante, o precioso metal! (...) Dele tão pouco quanto isto preciso para fazer do negro branco; do feio belo; do errado certo; do baixo nobre; do velho novo e do covarde valente. Oh deuses, porquê isto? Para quê isto, deuses? Dos vossos altares ele fará desertar sacerdotes e fiéis; ao doente, do travesseiro fará erguer a cabeça. Este escravo amarelo faz e desfaz votos sagrados; abençoa malditos; torna atractiva a repugnante lepra e enaltece os ladrões, garantindo-lhes títulos, genuflexões e a aprovação dos senadores. É ele que faz a viúva gasta casar-se de novo (...). Vem, mineral maldito! A ti, prostituta comum da humanidade, que semeias a discórdia das nações, far-te-ei voltar a ser o que eras.”

Ao contrário da grande maioria dos metais, que reflectem a luz branca sem que os nossos olhos consigam detectar alguma cor, o ouro é um metal de tons amarelos. Para se entender a cor do ouro tem de se fazer uma correcção relativística ao seu átomo. À medida que a carga nuclear $(Z)$ dos átomos aumenta, verifica-se um aumento da velocidade média dos electrões mais penetrantes (electrões $s$ ) e, como consequência da relatividade, da massa destes. Com efeito, os electrões $s$ (e em menor extensão os $p$ ) são mais atraídos pelo núcleo e as suas orbitais mais pequenas do que se este efeito relativístico não existisse. Simultaneamente, os electrões $d$ (e f) são menos atraídos e encontram-se em orbitais maiores quando este efeito é pronunciado, o qual, grosso modo, é proporcional a $Z^{2}$. Assim, o efeito relativístico torna-se importante para os elementos pós lantanídeos. No ouro ([Xe] $4 f^{14} 5 d^{10} 6 s^{1}$ ), verifica-se um intenso efeito relativístico que é responsável por este metal ser física e quimicamente bastante diferente da prata ([Kr] $\left.4 d^{10} 5 s^{1}\right)$. O aumento da energia dos electrões das orbitais $5 d$ e a diminuição da energia do electrão $6 s$ é responsável por uma absorção de radiação na zona do azul, associada à transição da banda $5 d$ para o nível de Fermi de carácter 6s. A correspondente absorção na prata (transição da banda $4 d$ para o nível de Fermi $~ 5 s$ ) ocorre, por sua vez, no ultravioleta [15-17].

Por se poder encontrar na natureza na forma metálica e ter um ponto de fusão relativamente baixo $\left(1064,4^{\circ} \mathrm{C}\right)$, o ouro terá sido um dos primeiros metais a ser trabalhado pelo Homem, o que terá acorrido no quarto milénio antes de Cristo, no Leste Europeu. Já mais tarde, por volta de 1200 a.C., os egípcios conseguiram dominar a arte de o bater em finas folhas e de lhe incorporar outros metais, obtendo ligas mais duras e de cores variadas [18]. Com efeito, o ouro é um metal muito maleável (forma fios finos) e dúctil (1 g de ouro, algo do tamanho de um grão de arroz, pode ser martelado até se converter numa folha de um metro quadrado). Além disso pode apresentar cores diferentes em função do metal com que é fundido. Assim, com 10\% de níquel dá o ouro branco; com 50\% de cobre origina o ouro vermelho; com 54\% de índio dá o ouro azul; com 20\% de alumínio obtém-se o ouro púrpura; com $27 \%$ de prata o ouro verde e com 25\% de cobalto o ouro preto. A sua pureza é habitualmente expressa em quilates: o ouro puro tem 24 quilates; o ouro de 18 quilates tem 75\% de ouro e o de 9 quilates possui somente $38 \%$ do metal (de forma geral o outro metal é o cobre) $[19,20]$.

Foi em 560 a.C., no reino da Lídia (na actual Anatólia, Turquia), que foram cunhadas as primeiras moedas de ouro purificado. Para esse efeito o ouro foi obtido a partir de electrum (uma liga metálica de ocorrência natural constituída por cerca de dois terços de ouro e um terço de prata) finamente divido e aquecido a $800^{\circ} \mathrm{C}$ na presença de cloreto de sódio. Este método permitia a remoção da prata por formação de cloreto de prata (processo conhecido em metalurgia por cementação). A lendária fortuna de Creso dever-se-ia à extracção de ouro das areias auríferas do rio Pactolo. ${ }^{7}$ Curiosamente este é o rio em que, de acordo com a lenda, Midas se terá banhado para anular a sentença divina de que tudo em que tocasse se transformaria em ouro $[9,10]$.

Apesar da grande inércia química deste metal, os alquimistas medievais conseguiram dissolve-lo numa mistura de ácido nítrico e ácido clorídrico (água régia); posteriormente, no séc. XVIII, Carl Scheele verificou que é igualmente solúvel em soluções de cianeto. Na actualidade, o ouro é maioritariamente obtido a partir dos seus minérios que, para o efeito, são tratados com uma solução de cianeto de sódio. O ião $\left[\mathrm{Au}(\mathrm{CN})_{4}\right]^{-}$resultante, por redução com zinco fornece o desejado metal sólido. Quanto à quantidade até hoje extraída da Terra, calcula-se que deverá ser o equivalente a um cubo com vinte metros de aresta [21,22].

\section{ETANOL}

La Fanciulla é irrefutavelmente uma “ópera de homens” e, por isso, nela só se bebe "bebida de homens" - o que quer

\footnotetext{
${ }^{7}$ A vida de Creso inspirou Reinhard Keise para a composição da ópera Croesus, estreada em Hamburgo em 1711
} 
dizer whisky: "Alla "Polka" si beve l' whisky schietto" (No "Polka” bebe-se whisky puro) (Figura 5). A palavra "whisky" é cantada onze vezes na ópera, sem contar com as múltiplas referências à bebida nas instruções de cena. No I acto, a virilidade de Dick Johnson chega a ser posta em causa quando pede whisky com água: "Mi ha chiesto un whisky ed acqua” (Pedi um whisky com água)”. O whisky, porém, não era algo inédito numa ópera de Puccini: no I acto de Madama Butterfly Pinkerton e Sharpless também o bebem!

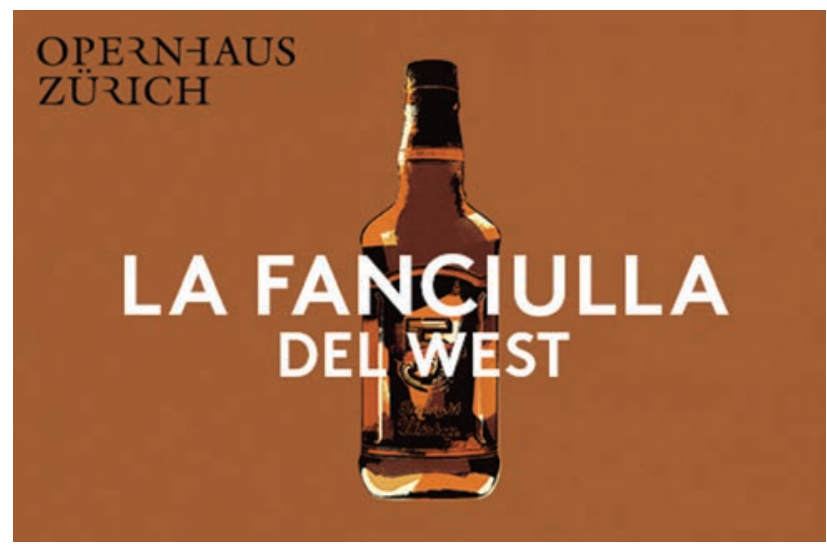

cas estão também patentes na bebida consumida na ópera (tal como em La Fanciulla). Assim, na siciliana Cavaleria Rusticana (Mascagni) Turidu despede-se da vida com vinho, enquanto que na checa $A$ Noiva Vendida (Smetana) se bebe cerveja e na russa Lady Macbeth do Distrito de Mtsensk (Shostakovitch), o velho bêbedo canta louvores à vodka. Já na famosa ária "Près des remparts de Séville", de Carmen (Bizet), a protagonista diz que irá dançar e beber manzanilla (xerez). Ainda n 'O Morcego, na czarda “Li klange der heimat”, a condessa húngara - que na verdade

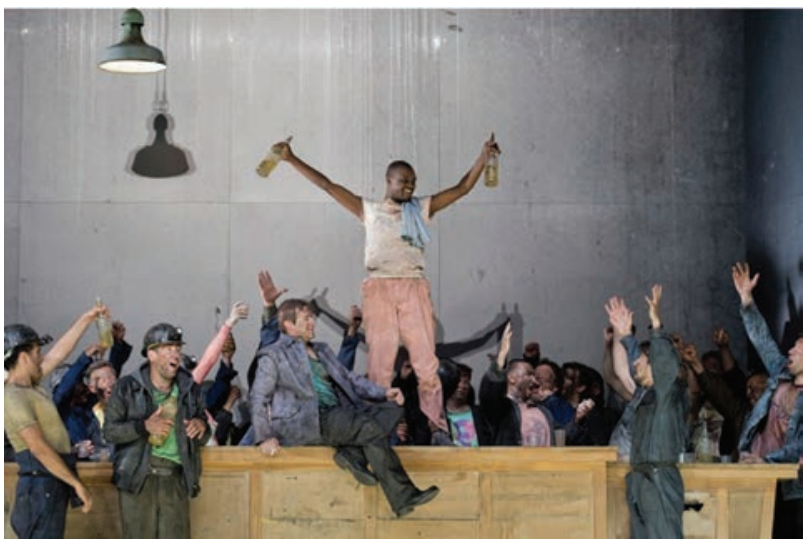

Figura 5 - Cartaz de La Fanciulla del West na Ópera de Zurique (temporada de 2013-14) e uma cena do I acto da mesma produção suíça (@) Monika Rittershaus/Opernhaus Zürich)

O álcool, e em particular o vinho, é, de resto, uma presença comum nos libretos de Ópera - uma temática, aliás, já abordada por Jorge Calado neste boletim, no artigo "Wine, Chemistry and Song” (vide ref. 23).

Com efeito, a Ópera tanto exalta as virtudes do etanol como o usa como elemento de caracterização de personagens e situações. Exemplos disso são a efervescente ária de Don Giovanni (Mozart) "Fin ch’ han dal vino” (“ária do champanhe”); "Il segreto per esser felice” de Lucrezia Borgia (Donizetti); "Vivat Bacchus! Semper vivat!” de Werther (Massenet); "Ô vin, dissipe la tristesse” de Hamlet (Thomas); "Conciossiacosaché” de La Cenerentola (Rossini) ou o coro "Vin ou bière" de Faust (Gounod). Em Verdi encontramos três brindes famosos: o "Libiamo" de $L a$ Traviata; o de Lady Macbeth no banquete do II acto de Macbeth ("Si colmi il calice di vino eletto") e, em Otello, o brinde de Cassio a Desdemona e Otello, enquanto Iago lhe mantém o copo cheio e canta "Inaffia l'ugola!” ("Molha a goela!”). No I acto d' O Morcego (J. Strauss) canta-se "Trinke, Liebchen, trinke schnell. Trinken macht die Augen hell” ("Bebe minha querida, bebe depressa que beber faz brilhar os olhos”) para logo de seguida, na festa do Príncipe Orlofsky, em "Im Feuerstrom der Reben" ("O fogo que corre na videira”), se aclamarem as virtudes do champanhe. Em Fedora (Giordano) vai-se ainda mais longe, enaltecendo-se uma marca: "Veuve Clicquot". Por sua vez Falstaff (Verdi), muito English, encharcava-se em xerez e pedia vin caldo (vinho aquecido). Na opereta $L a$ Périchole (Offenbach), na deliciosa aria “Ah! Quel diner je viens de faire” o título fala por si mesmo. Em Tosca (Puccini), Scarpia oferece vinho de Espanha à protagonista e em L'Elisir d'Amore (Donizetti) o vinho de Bordéus é o próprio elixir. As condicionantes culturais e geográfi- é Rosalinde - num baile de máscaras em Viena, evoca a sua terra natal ao olhar para um cálice de Tokay. Na ópera brasileira Il Guarany (Gomes), com colonos portugueses entre as personagens, bebe-se, como não podia deixar de ser, vinho do Porto: "versate il porto...”.

\subsection{A FERMENTAÇÃO}

Antoine Lavoisier foi pioneiro no reconhecimento de que o açúcar por acção de leveduras se converte em dióxido de carbono e espírito de vinho, que designou por álcool (vocábulo de origem árabe). No decurso da investigação sobre a fermentação vínica verificou que a massa do mosto das uvas de que partia era igual à soma das massas de ácido carbónico $\left(\mathrm{CO}_{2}\right)$ e de álcool formados, constituindo esta a base do seu enunciado da lei da conservação da massa [24]. Lavoisier também descreveu correctamente o álcool (etanol) como um composto de carbono, hidrogénio e oxigénio. Seria porém Nicolas-Théodore de Saussure, em 1807, quem determinaria a sua fórmula [25] e Archibald Scott Couper, meio século depois, quem chegaria à fórmula estrutural [26].

É oportuno referir que foi numa fábrica de cerveja em Leeds, em 1771, que Joseph Priestley recolheu o dióxido de carbono obtido da fermentação. Chamou-lhe "ar fixo" e verificou que é um gás hidrossolúvel que confere à água um certo pique agradável. Dessa sua investigação resultou o famoso artigo "Impregnating Water with Fixed Air" (1772), que acabaria por estabelecer as bases para a produção de águas e bebidas carbonatadas [27].

Até 1840 a fermentação foi vista como um fenómeno estritamente químico, para o que contribuiu a influência de 
químicos da craveira de Berzelius, Wöhler e Liebig, que embora reconhecessem o papel crucial da levedura a concebiam como algo inanimado. Para Liebig, fermentação e putrefacção seriam até processos da mesma natureza, sendo as vibrações emanadas da decomposição da matéria orgânica que, espalhando-se ao açúcar, permitiam que deste se obtivesse etanol e dióxido de carbono [29].

Para que a fermentação passasse a ser encarada como um processo de natureza biológica foram cruciais as contribuições de Theodor Schwann, Cagniard de Latour e Friedrich Kützing, pioneiros da microbiologia que abriram o caminho a Louis Pasteur. É digno de destaque especial o papel de Theodor Schwann que, em 1836, concluiu ser um microorganismo a entidade responsável pela fermentação. Chamou-lhe, de forma definitiva, Saccharomyces (do latim "fungo do açúcar”) [29].

O interesse de Pasteur pelo fenómeno da fermentação começou em 1854, no seguimento dos estudos sobre a actividade óptica do álcool amílico activo (2-metil-1-butanol), um dos álcoois obtidos na fermentação alcoólica. Ao longo das duas décadas seguintes, Pasteur acabaria por demonstrar que a fermentação é um processo biogénico, derrubando assim, de uma vez por todas, a teoria da geração espontânea. Igualmente conseguiu identificar os microrganismos responsáveis pelos diversos tipos de fermentação. Os estudos efectuados sobre a fermentação butírica, na qual os microrganismos se desenvolvem na ausência de oxigénio, levaram-no a distinguir entre microrganismos aeróbios e anaeróbios. A sua ideia fulcral de que a fermentação tinha origem no metabolismo celular, sendo por isso só viável na presença de células vivas, conseguiu resistir até 1897, ano em que Eduard Buchner verificou que o extracto líquido obtido a partir da trituração das leveduras também conseguia converter o açúcar em dióxido de carbono e etanol. Esta descoberta acabaria por revelar-se essencial para a compreensão de que a fermentação alcoólica é um processo que depende, afinal, da acção de enzimas produzidas pelas leveduras. Por este trabalho, Buchner recebeu em 1907 o Prémio Nobel da Química [28].

\subsection{A destilação}

No século XII, quando os europeus começaram a repelir os ocupantes muçulmanos deram conta do enorme legado cultural e científico deixado por estes. Entre muitas heranças ficou o alambique, que de acordo com alguns autores teria sido já inventado na civilização greco-romana, a partir da observação de Dioscórides (ca 40-90 da era cristã) de que o mercúrio condensava na parte inferior da tampa de um pote [28]. No entanto, segundo outros, terá sido criado a partir do kerotakis - um dispositivo para sublimação e destilação de substâncias - pela alquimista Maria, a Judia, que viveu no Egipto no séc. III a.C., a quem também é atribuída a invenção do banho-maria [30]. Aristóteles (384-322 a.C.) terá igualmente investigado o fundamento da destilação e conseguido mesmo obter água a partir de vinho [29,31]. Pese tudo isto, o mais antigo registo conhecido da obtenção de etanol por destilação do vinho refere-se aos alquimistas da escola de Salerno no séc. XII [32].

Apesar da importância do legado árabe na arte da destilação, o alambique muçulmano era feito de materiais maus condutores de calor - vidro e cerâmica -, daí ser pouco eficaz na condensação. A Europa pós-árabe introduziu-lhe dois grandes melhoramentos: o rosenhütte (Figura 6) e a “cabeça de mouro”. O primeiro consistia numa cabeça cónica feita de metal e o segundo num contentor de água, feito de vidro ou barro, que se podia colocar em torno do alambique.

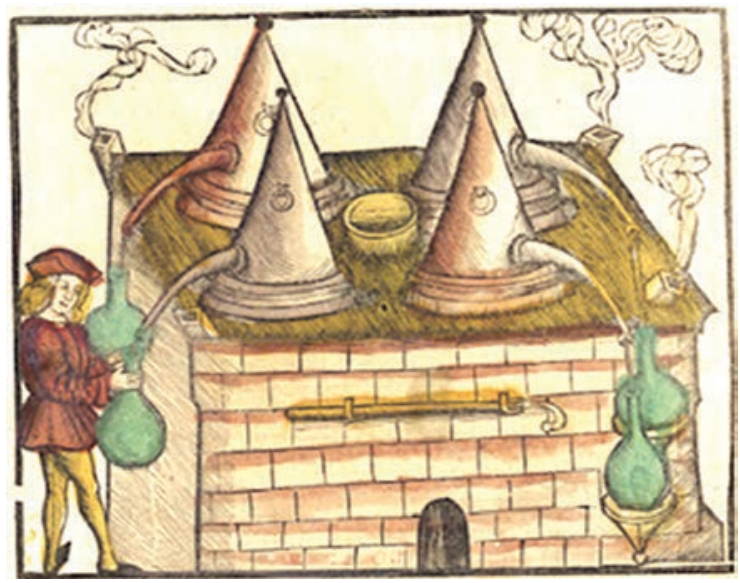

Figura 6 - Dispositivo de destilação com rosenhütte (ilustração do livro de destilação de Hieronymus Brunschwig [33])

Simultaneamente assistiu-se à tradução para latim das obras alquímicas de autores importantes como Geber (c.721 c.815). Tornou-se assim possível obter destilados de álcool de elevada concentração, entre eles a aqua ardens (metanol) e a aqua vitae (etanol). Levaria ainda algum tempo até que os destilados alcoólicos saíssem dos laboratórios dos alquimistas para serem usados pelas populações mas o mundo cristão, outrora livre dos espíritos alcoólicos, aos poucos rendia-se às suas virtudes medicinais e recreativas $[28,34]$.

A aguardente (aqua vini) terá sido a primeira bebida alcoólica destilada utilizada no mundo ocidental, o que até ao séc. XVI foi essencialmente com fins médicos, sobretudo como narcótico. Com o aperfeiçoamento da arte da destilação, o etanol passou a ser considerado de maior valor terapêutico que o próprio vinho. Raimundo Lully (c.1232-1315), discípulo de Arnaldo de Villanova (vide infra), foi o primeiro europeu a escrever sobre destilados. Para Lully estes eram algo distinto do vinho de onde provinham, ou não fosse a destilação entendida como uma arte transformadora. A substância obtida constituía mesmo uma emanação divina, um elemento novo que se revelava ao Homem. Chamou-se-lhe então quintessência, ou seja, o quinto elemento aristotélico, formador dos corpos celestes e congregador de todas as virtudes que a matéria podia oferecer. Considerava-se que a extracção da quintessência dos materiais, encarada como uma aproximação a Deus, era facilitada se estes fossem previamente macerados em aqua vitae e de seguida destilados ou, em alternativa, destilados depois de entrarem em putrefacção (considerada uma fermentação). 
Esta visão alquímica da destilação ficou expressa num dos livros que, no género, maior difusão teve na Europa medieval: Liber de arte distillandi simplicia et composita, da autoria do cirurgião Hieronymus Brunschwig de Estrasburgo, publicado em 1500 (Figura 7). A ideia da extracção das "virtudes" dos materiais subsistiu na linguagem científica ao longo dos tempos: repare-se que ainda hoje nos referimos à “extracção de essências”... [29,31].

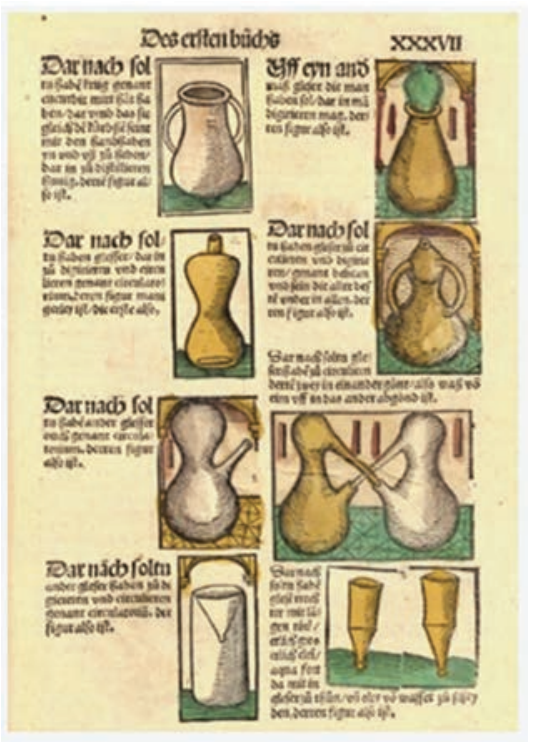

Figura 7 - Ilustração do livro de Hieronymus Brunschwig [33]

\subsection{O GOSTO DE BEBER}

Existem vários achados arqueológicos que, conjuntamente com as respectivas análises químicas e de datação, têm revelado que a preparação ancestral de bebidas alcoólicas poderá remontar, no mínimo, a 7000 anos a.C., na China. Tal terá acontecido assim que os humanos se dedicaram à agricultura e criaram comunidades sedentárias. No entanto os hábitos de "intoxicação recreativa" já existiriam antes da invenção da cerveja, ou de algo análogo. Com efeito, os dados paleobotânicos conhecidos, bem como as representações de fenómenos entópticos nas pinturas de cavernas, datadas de há mais de 30000 anos, sugerem que alguns dos nossos ancestrais consumiriam cogumelos alucinogénicos, canábis e papoilas do ópio para fins recreativos. Este entendimento permite-nos admitir que o álcool, como agente psicotrópico, possa igualmente ter sido bem recebido desde o início [29,35]. Até à introdução dos destilados alcoólicos na Europa, as populações tinham desenvolvido uma cultura associada a grandes consumos de cerveja ou de vinho. O vinho, com efeito, constituía algo de sacro-medicinal: tanto era usado na doença como nas celebrações da eucaristia. Arnaldo de Villanova, no seu Liber de Vinis (13091311), defendeu entusiasticamente o vinho como panaceia para todos os males. Desse tempo ficaram-nos importantes obras testemunhais como os poemas profanos Carmina Burana (escritos desde o séc. XI até ao séc. XIII e musicados no séc. XX por Carl Orff, e dos quais, por analogia com o "Polka” de Minnie, se destaca a secção "In Taberna”) e Os Contos de Canterbury, escritos por Geoffrey Chaucer nos finais do séc. XIV (Chaucer, um dos autores pioneiros da literatura inglesa, foi também praticante da alquimia).
Terá sido no séc. XVI que os destiladores da região de Cognac, em França, exploraram as virtudes de uma segunda destilação. Esta, conjuntamente com uma longa maturação do destilado em cascos de madeira, suavizava a bebida tornando-a mais agradável para consumo. As vantagens da dupla destilação acabariam igualmente por ser exploradas pelos irlandeses e escoceses, tendo a designação do equivalente gaélico de aqua vitae - uisge beatha ou usquebaugh - sido anglicizada e encurtada para whiskey/whisky no séc. XVIII [36].

Embora se possa escrever uma História Universal baseada no álcool, no presente contexto - a ópera La Fanciulla interessa sobretudo que nos centremos no Oeste dos EUA por altura da Gold Rush. O povoamento europeu desta região americana tinha sido sucessivamente adiado ao longo dos tempos, acabando por só ocorrer poucas décadas antes da Declaração de Independência (1776). Para isso foi necessário que os colonos ousassem finalmente afastar-se do Estado da Virgínia, onde inicialmente se tinham instalado, rumando para além dos Montes Allegheny (uma espécie de fronteira entre o território colonial britânico e o que era destinado às reservas de índios americanos). Grande parte destes aventureiros era de origem Scottish-Irish ${ }^{8}$. Ao contrário dos colonos instalados em cidades e povoados, os Scottish Irish preferiram rumar a Oeste, para o interior do continente, para além dos limites da jurisdição governamental, onde acreditavam poder viver de acordo com os seus ideais de independência. A promessa de terra grátis e de ausência de impostos tornava o empreendimento ainda mais atractivo. Enfrentavam, sem dúvida, a permanente ameaça assassina de algumas tribos índias mas a vida que tinham deixado para trás também não lhes parecia mais animadora. A receita para sobreviver neste “idílio” passava, obviamente, pela capacidade de auto-suficiência, o que incluía munições e whisky. Para estes colonos, a arte de destilar a "água da vida” fazia parte do legado adquirido desde tempos remotos. Numa “emergência”, a um Scottish Irish bastavam milho, água, fogo, uma chaleira e uma toalha molhada para que produzisse whisky. O líquido assim obtido possuía múltiplas vantagens práticas (principalmente para além dos Montes Allegheny): era mais raro (e por isso mais valioso), mais fácil de transportar e menos perecível do que o cereal de onde provinha, sendo também facilmente convertível em terra, armas e comida [29].

A partir de 1700, nalgumas colónias americanas tinha-se começado a produzir destilados de centeio e de cevada, tendo o whisky de milho do Kentucky, o famoso bourbon, aparecido por volta de 1780 [36]. Uma grande parte dos destilados americanos destinava-se às populações nativas da nação, as quais constituíam um mercado tentador. Com efeito, os índios consumiam muito e pagavam em dinheiro vivo (que recebiam do Estado como compensação por se manterem em reservas) [29]. A sua atracção pela bebida (ilustrada em La Fanciulla pela figura do índio Billy Jackrabbit: "Dopo sposare: avere perle e whisky" - De-

\footnotetext{
8 Designação dada aos presbiterianos e outros dissidentes protestantes oriundos da província irlandesa do Ulster, a maioria descendente dos colonizadores escoceses e ingleses desta região no séc. XVII
} 
pois de casar terei contas e whisky), não raramente acabava em violência e ruina física.

Durante a Gold Rush, o álcool era o grande sedativo dos mineiros (Figura 8), como bem se vê no I acto de La Fanciulla, no "Polka".
Como não há bem que sempre dure, a uma "boa sessão" de bebida, não raramente, segue-se uma penosa sessão de ressaca. A desagradável sensação de se ter bebido demais está sobretudo associada à formação de acetaldeído no fígado, como resultado da oxidação do etanol. O acetaldeído é um composto tóxico que se crê poder estar na origem de

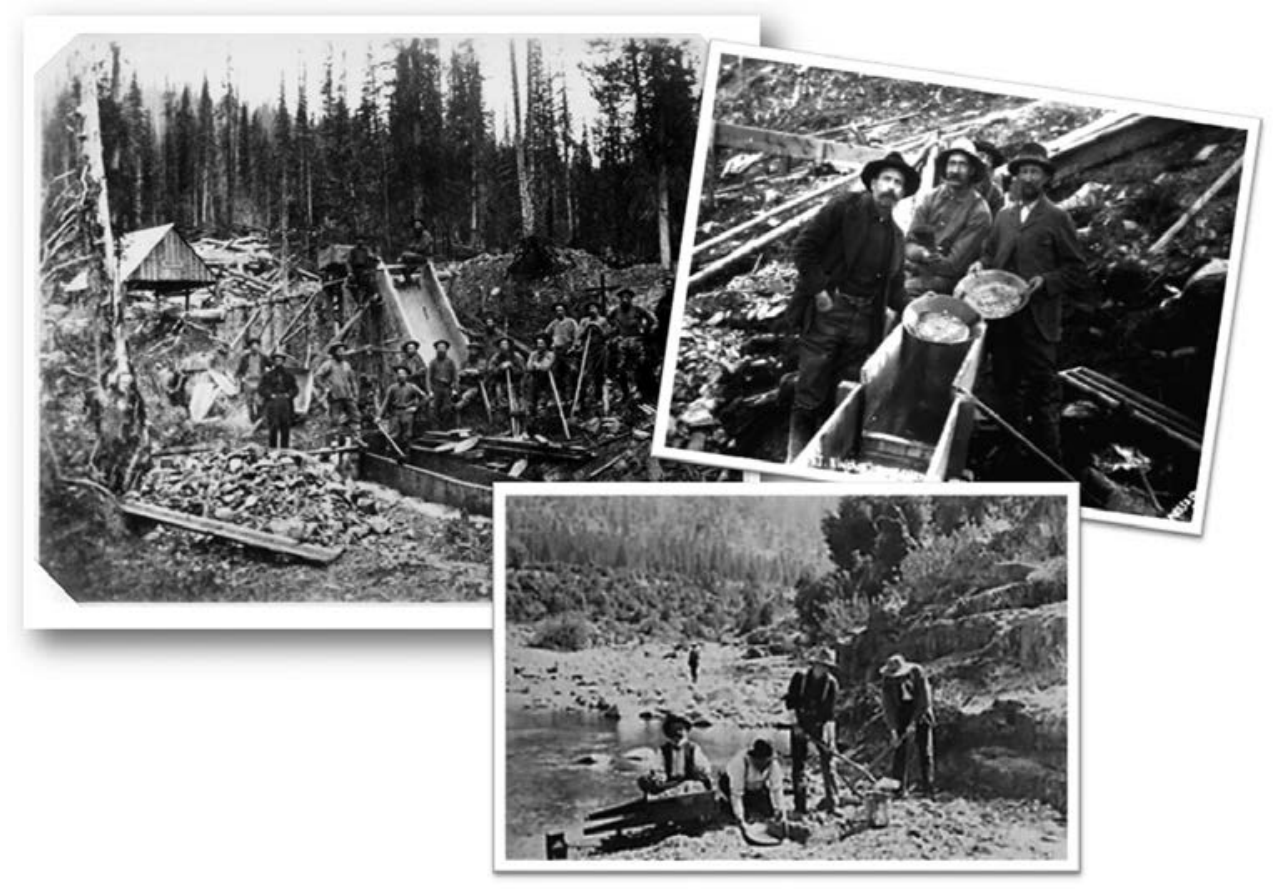

Figura 8 - Os verdadeiros protagonistas da Gold Rush da Califórnia (1848-1855)

O trabalho destes homens, que decorria maioritariamente em depósitos aluviais, era de grande dureza: chegavam a trabalhar catorze horas diárias, muitas vezes imersos em correntes de água. As condições climatéricas imprevisíveis nas montanhas - calores escaldantes e nevões que, na primavera e no outono, chegam a coexistir numa mesma semana; os longos nevões no inverno (a tempestade de neve no II acto de La Fanciulla!) e as súbitas enxurradas de água no verão - tornavam a actividade mineira ainda mais penosa. No I acto da ópera, Minnie, usando um vocabulário algo químico, ajuda-nos mais uma vez a entender quão dura era a actividade dos mineiros: "E una lotta superba! L'alcali, il sasso, la creta, la zolla: tutto è nemico! S'accoscian sull'erba umida: il fango negli ocelli, nell'ossa, nel cuore!” (É uma luta colossal! Álcalis, rochas, barro, terra: tudo é inimigo! Exploram o solo húmido e sujo e a lama entra-lhes nos olhos, nos ossos e no coração!). Em Shirley Letters [37], Louise A. K. S. Clappe retratou os hábitos de vida (e de bebida!) daqueles homens, baseada na vivência que teve, entre 1851 e 1852, em dois acampamentos de mineiros na Califórnia do Norte. Naquele ambiente recôndito, profundamente masculino e rude, apesar de acompanhada pelo marido - médico -, Louise terá sido uma espécie de Minnie para todos eles.

Curiosamente, o hábito de beber para afogar as mágoas da vida aparece-nos ainda noutra ópera de Puccini: Il Tabarro. Nela, o estivador Tinca diz que "quem bebe não pensa; quem pensa não ri”. condições como artrite reumatóide, doença de Alzheimer e ataque cardíaco e de vários tipos de cancro. Felizmente o nosso organismo possui enzimas como as aldeído desidrogenases que oxidam o acetaldeído a ácido acético, que é inofensivo [38].

Quanto à velha crença do etanol ser um afrodisíaco, a ciência moderna mais não fez do que provar quão certeiras eram, afinal, as palavras do porteiro dirigidas a Macduff na cena 3 do II acto de Macbeth de Shakespeare [39]:

\footnotetext{
“ [...] a bebida, senhor, é grande causadora de três coisas [...]. Pois, nariz vermelho, sono e vontade de urinar. Quanto à luxúria, senhor, a bebida atiça e não atiça; atiça o desejo, mas impede ao mesmo tempo que o gozemos. Pode pois dizer-se que, em excesso, a bebida aldraba a luxúria: ora a incha, ora a desincha; ora a faz, ora a desfaz; tão depressa a instiga, como logo a amolece; tão cedo a ergue firme e altaneira como logo a derruba. A luxúria, em resumo, é aldrabada p’ la bebida, que a engana com o sono, a põe a urinar e a leva, por fim, a baquear.”
}

\section{NiCOTINA}

Na acção de La Fanciulla o acto de fumar está omnipresente, sendo os charutos referidos quinze vezes no libreto (incluindo as indicações de cena). A par do consumo de whisky, fumar era um dos escassos prazeres dos mineiros 
da Gold Rush. No I acto da ópera, ao oferecer charutos ao agente da Wells Fargo, Minnie faz mesmo alusão a várias marcas: "Regalias? Auroras? Eurekas?”.

O próprio Puccini foi um fumador inveterado (Figura 9), tendo começado a fumar aos dezasseis anos (morreu com cancro da garganta! [40]). Ademais, tendo sido um compositor da corrente do Verismo (Realismo), o acto de fumar não constituiu nada de inusitado nas suas óperas: Butterfly (Cio-Cio San) oferece a Sharpless um dos cigarros que Pinkerton deixou quando a abandonou e em Il Tabarro o acender de um cachimbo, na escuridão do Sena, é o elemento desencadeador do trágico final. Poderá notar-se também que, nesta ópera, o apagar do cachimbo de Michele constitui, por sua vez, uma metáfora para a sua perda de vigor sexual (a mulher chega a dizer-lhe: "Dalla tua pipa il fiume bianco non sbuffa più ” (Do teu cachimbo já não sai fumaça)). Pelo contrário, em La Fanciulla, os charutos que Jack Rance ostensivamente fuma constituem um símbolo da sua virilidade e do desejo que sente por Minnie [41] vide secção ÓXIDO NÍTRICO.

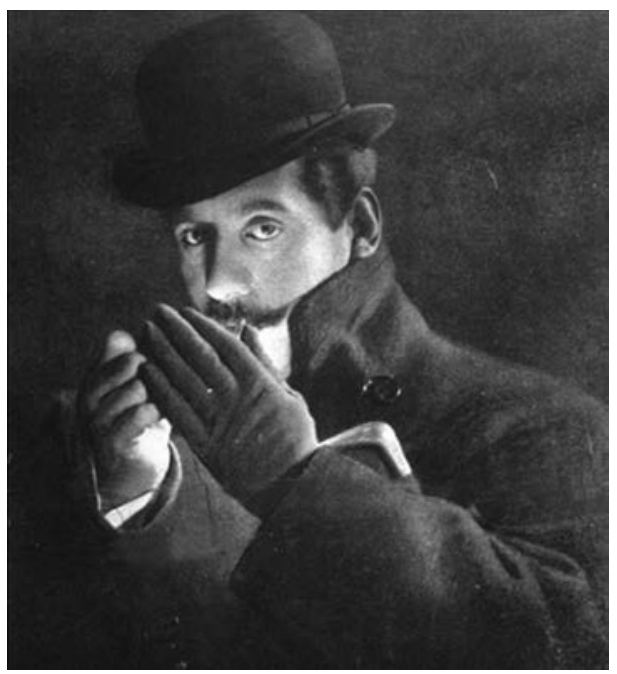

Figura 9 - Giacomo Puccini (1858-1924)

Temos de recuar até ao séc. XVIII para podermos encontrar numa ópera o consumo explícito de tabaco: na cena 1 do II acto de The Beggar's Opera (1728), de John Gay e Johan Pepusch, sobre a mesa duma taberna inglesa, onde se juntam vários bandidos de estrada, encontram-se vinho, brandy e tabaco. Nesta época a classe alta inglesa tinha imposto a moda do consumo de tabaco por inalação (este, reduzido a pó, originou a designação "pitada de rapé”, que tão bem conhecemos da escrita de autores como Eça de Queirós ou Camilo Castelo Branco). Em lugares como a taberna em que decorre a acção de The Beggar's Opera, o tabaco era vulgarmente consumido por inalação do fumo, um hábito que, como se sabe, se haveria de generalizar. Falando de tabernas, de fumo e de ópera, é forçoso referir Les Contes d'Hoffmann (Offenbach), em que numa taberna de Nuremberga se bebe e se fuma: "Je bois, fume et m’assieds commme vous”. Em Carmen (Bizet), a protagonista, operária numa fábrica de charutos de Sevilha, fuma, assim como também fumam, "para matar o tempo" ("On fume, on jase...”), os soldados que a esperam à saída do emprego. Não obstante, a mais emblemática ópera associada ao tabagismo será Il Segreto di Susanna (Wolf-Ferrari). O segredo de Susanna era afinal, e tão somente, o gostar de fumar (a ópera é de 1909!). Susanna, num desabafo algo delirante, chega a dizer-nos que "a doçura do cigarro é sensual e acariciante" e que "as delicadas espirais de fumo inspiram os nossos sonhos”.

A planta do tabaco, do género Nicotiana, da família das Solanaceae [42], foi trazida para a Europa por Cristóvão Colombo, que a tinha visto ser consumida pelos nativos americanos - fumada, inalada ou mascada - tanto para fins rituais como recreativos. Em 1560 a planta terá chegado a Portugal, de onde logo o embaixador de França, Jean Nicot, a enviou para a corte francesa. Nicot, tendo verificado como um cataplasma feito à base de folhas de tabaco rapidamente tinha curado uma ferida no polegar do seu cozinheiro, não hesitou em recomendar a nova planta à sua rainha, Catarina de Médicis, grande sofredora de enxaquecas. Daí não tardou até que toda a corte usasse a "Herba Medicea" ou "Herba Catherinea" das mais variadas formas [35,41]. O uso da planta não colheu, porém, todas as simpatias da época, tendo sido alvo de várias proibições, tanto régias como papais. Apesar de tudo, graças aos marinheiros portugueses e espanhóis, o consumo de tabaco conseguiu implantar-se, sobretudo a partir dos locais onde existisse um porto de mar [43].

A planta do tabaco é rica em alcalóides piridínicos e piperidínicos, de entre os quais se destaca a nicotina (2-8 \%, Figura 10) - repare-se como o nome de Nicot ficou para sempre associado tanto à planta como ao seu principal alcalóide!

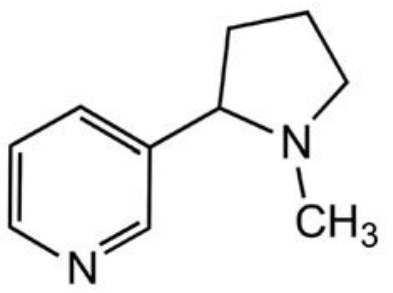

Figura 10 - Estrutura da nicotina

No Homem, a nicotina é absorvida pelas mucosas, estimulando o sistema nervoso central e o centro respiratório, para de seguida, em doses elevadas, os deprimir. O tabagismo contribui para condições como a aterosclerose e as doenças do coração, para além de, durante a combustão do tabaco, se formarem alcatrões que são cancerígenos, principalmente os derivados dos colantrenos, responsáveis por muitos cancros do pulmão [44].

\section{OxIDO NítRICO}

Sendo o amor, a atracção física e sexual e o próprio acto sexual condicionados por uma panóplia de moléculas envolvidas em complexas redes de interacções [45], pode dizer-se que numa ópera como La Fanciulla estas moléculas assumem estatuto de grandes protagonistas. No II acto, que tem uma inegável "carga sexual”, chega a estabelecer-se o 
seguinte diálogo entre Minnie e Johnson, que não é de todo desprovido de segundos sentidos:

Minnie: “Per me l'amore è una cosa infinita! Non potrò mai capire come si possa, amando una persona desiderarla per un' ora sola." (Para mim o amor é para sempre! Não consigo entender que amando-se uma pessoa se possa desejá-la só por uma hora.).

Johnson: "Credo che abbiate torto. Vi sono delle donne che si vorrebber nella nostra vita per quell'ora soltanto... E poi morire!" (Creio que está enganada. Há mulheres que de bom grado teríamos na nossa vida nem que fosse por uma hora... Para depois morrer!).

Minnie (com malícia, chegando-se a Johnson e oferecendo-lhe um charuto): "Davvero? E... quante volte siete morto?” (Ah sim? E quantas vezes já morreu?).

A propósito desta troca insinuante de palavras houve já quem tivesse sugerido que a célebre afirmação de Freud sobre charutos deveria ser alterada para "por vezes um charuto não é só um charuto” [41].

Posteriormente é Jack Rance (casado!) que, avançando sobre Minnie e abraçando-a, lhe diz: "Sono pazzo di te!... T'amo e ti voglio!" (Estou doido por ti!... Amo-te e desejo-te!). Minnie defende-se como pode (Figura 11).

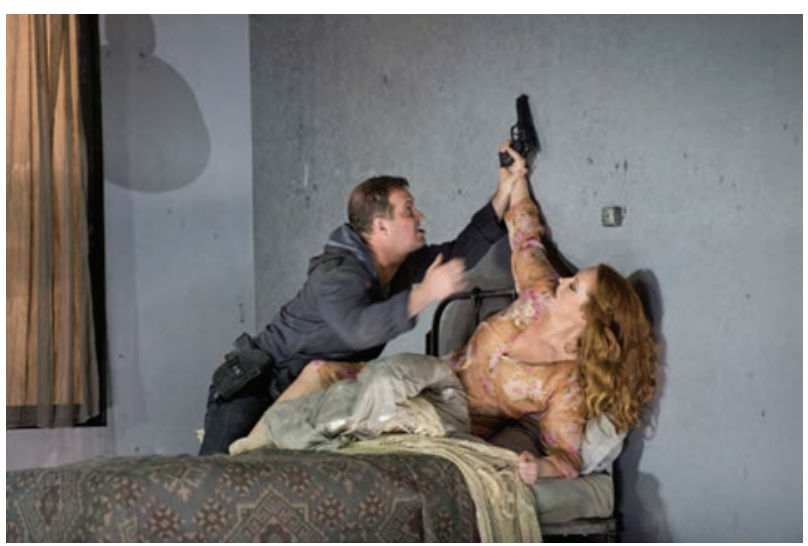

Figura 11 - Scott Hendricks (Rance) e Catherine Naglestad (Minnie) na Ópera de Zurique, 2014 (C Monika Rittershaus/Opernhaus Zürich)

De seguida, numa das cenas mais empolgantes de toda a ópera, Minnie e Rance aceitam jogar uma partida de poker que irá decidir a sorte de Johnson (que, entretanto ferido, se esvai em sangue). Se Rance ganhar poderá aprisionar Johnson e - muito mais importante - possuir Minnie por uma noite; se perder, Johnson será restituído à sua amada (Figura 12).

Onde aparece o óxido nítrico nisto tudo? Bom, já não é exactamente uma novidade que a lábil molécula diatómica NO - na verdade um radical livre, por possuir um electrão desemparelhado - desempenha um papel fundamental na sexualidade, por estar na origem do fenómeno da erecção. Este boletim, num belo artigo de Jorge Calado, abordou o tema nos anos 90 do século passado, quando a descoberta era ainda recente (vide ref. 46).

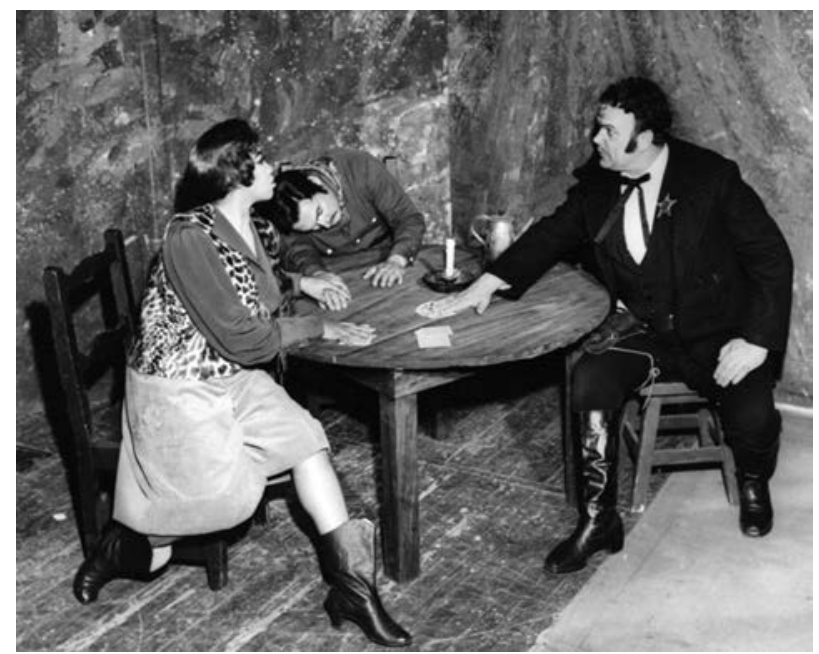

Figura 12 - Leontyne Price (numa rara aparição como Minnie), Richard Tucker (Johnson) e Anselmo Colzani (Rance) no MET, 1961 ( Louis Melancon/The Metropolitan Opera Archives)

Olhando retrospectivamente, a investigação dos óxidos de nitrogénio remonta a Priestley, que terá descoberto o óxido nítrico (por ele designado “ar nitroso”), e a Humphry Davy, que realizou as primeiras experiências fisiológicas com o NO ao investigar os efeitos de vários gases sobre os sistemas respiratório e circulatório $[47,48]$. Davy verificou de imediato que a inalação de óxido nítrico por animais lhes provocava a morte, ficando os tecidos destes com um tom vermelho-arroxeado (que hoje se sabe dever-se à coordenação do NO com o ferro hémico) [48-50].

Em finais dos anos 80 do século $\mathrm{XX}$ - quando já se sabia que o NO é um composto que faz parte do ciclo do nitrogénio e que está envolvido na criação do smog fotoquímico e das chuvas ácidas - descobriu-se finalmente que as células que revestem os vasos sanguíneos libertam pequenas quantidades de NO, provocando o relaxamento das paredes musculares dos vasos. Na senda desta descoberta, em 1991 descobriu-se que é o NO que activa a erecção do pénis. Com efeito, os pensamentos eróticos do homem enviam um sinal nervoso que activa a libertação de NO nos músculos do pénis, actuando como mensageiro de vasodilatação. De um modo um pouco mais detalhado, o seu mecanismo de acção é o seguinte: o NO, produzido a partir da oxidação da L-arginina pela NO-sintase, difunde-se pelo músculo liso do órgão sexual masculino, activando a guanilato ciclase que desencadeia uma sequência de reacções que conduzem a um aumento da produção de monofosfato cíclico de guanosina que, por sua vez, activa o efluxo de iões cálcio. A saída de cálcio leva a um relaxamento muscular do corpo cavernoso, causando a vasodilatação e permitindo, consequentemente, um aumento do fluxo sanguíneo no pénis, com os resultados - "mais ou menos espectaculares" [46] - que se conhecem [51]. Crê-se que a erecção clitoriana também seja mediada pelo NO [52].

À molécula de NO haveria de ser reconhecido o estatuto de mensageiro celular ubíquo nos sistemas cardiovascular, imunitário e nervoso, o que a revista Science destacou, elegendo-a em 1992 como "molécula do ano” (Figura 13) 
[50]. Acresce que em 1998 o Prémio Nobel da Medicina foi atribuído a R. F. Furchgott, L. J. Ignarro e F. Murad pelas "suas descobertas relativamente ao óxido nítrico como molécula sinalizadora no sistema cardiovascular” [53].

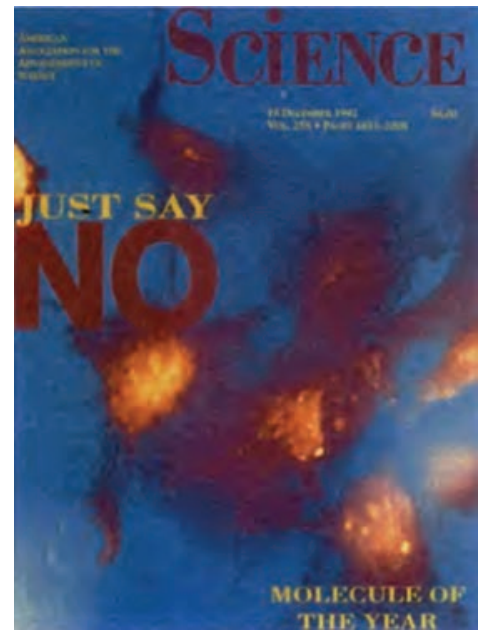

Figura 13 - Capa da revista Science dedicada ao NO (17 de Dezembro de 1992)

Na Ópera, as moléculas do amor e do sexo, em particular o NO, deixam também a sua marca indelével em personagens do calibre de Don Giovanni (Don Giovanni, Mozart); Duque de Mântua (Rigoletto, Verdi); Calaf (Turandot, Puccini), com a sua erecção perpétua, como já alguém referiu [54]; Conde de Luna (Il Trovatore, Verdi); Scarpia (Tosca, Puccini) ou Osaka, o violador de Iris (Iris, Mascagni). Ressalve-se que estas moléculas (NO incluído) não actuam só neles [52] mas, quanto a género e sexualidade, a ópera é, por regra, muito mais condescendente com o feminino. As excepções serão as personagens-título das obras Carmen (Bizet), Lulu (Berg) e Manon (talvez mais a de Puccini que a de Massenet), já para não falar da ninfomaníaca Duquesa de Argyll, personagem tirada da vida real e retratada em Powder Her Face (Adès). Em La Fanciulla há ainda que mencionar uma figura que, embora nunca aparecendo em cena, é referida por diversas vezes e tudo indica ser bem conhecida dos rapazes: Nina Micheltorena. No I acto (descontados os ciúmes), Minnie dá-nos a entender que não se trata exactamente de um modelo de virtude: "É una tìnta spagnuola nativa di Cachuca, una sirena che fa molto consumo di nerofumo per farsi l'occhio languido... Chiedetene ai ragazzi!” (É uma bela espanhola, natural de Cachuca; uma sereia de olho lânguido à custa de muito lápis preto. Pergunte aos rapazes por ela!). E o que é que faz mover a fogosa Katerina Izmailova e o seu amante em Lady Macbeth de Mtsensk (Shostakovitch)? Em caso de dúvida a resposta é-nos dada no II acto pela própria orquestra, através das poderosas texturas orquestrais dos sopros e dos incessantes ritmos pulsantes. O pós-clímax desta cena é-nos sugestivamente indicado pelos glissandi do trombone. Foi uma ópera tão revolucionária para a época que houve quem dissesse tratar-se de mera "pornofonia”. E o que dizer do prelúdio de Der Rosenkavalier (R. Strauss)? Não será uma verdadeira transcrição musical do acto sexual?

Para além do grupo de conquistadores/libertinos/predadores, ou só meros insaciáveis, referidos neste texto, é, toda- via, n’ A Flauta Mágica de Mozart que podemos encontrar o melhor exemplo operático do NO ao serviço do puro desejo carnal aliado ao amor: Papageno e Papagena, no célebre dueto "Pa...pa...pa...", declaram, tão-somente, que desejam... fazer muitos bebés um com o outro!

\section{CODA}

Pela via dos venenos, ingredientes clássicos geradores de tramas "fatais", a Química está presente de forma óbvia e frequente nos libretos de ópera [6]. La Fanciulla del West, ópera de enorme potencial educativo, permite-nos, porém, ir mais longe no estabelecimento de pontes entre Química e Ópera: o seu enredo, de forma directa ou indirecta, possibilita a (re)visitação de temas e questões da Ciência, em particular da Química, assim como da sua História e da História Universal. Não deverá, por isso, estranhar-se a inclusão de La Fanciulla no projecto educativo do MET “The Metropolitan Opera In Schools”, destinado a levar as transmissões de ópera em alta definição a várias escolas dos EUA [55]. Acrescente-se que o site do MET faculta um guião para exploração pedagógica desta ópera [56]. Tratando-se de uma história de “amor versus justiça”, levanta, naturalmente, várias questões éticas: será Dick Johnson um verdadeiro criminoso?; merecerá ele o perdão? Se sim, com base em quê? E Minnie, no final age mesmo como uma heroína?

A apresentação de La Fanciulla del West nas salas de aula, no âmbito de um grande projecto interdisciplinar (Química, Música, Literatura, História, Filosofia,...), poderia revelar-se uma experiência pedagógica inédita e interessante. Haverá alguma escola portuguesa que ouse tentar um projecto desta natureza? Assinale-se que existem várias versões da ópera em DVD, das quais se destacam as seguintes:

- Stemme, Antonenko, Lundgren; Royal Opera House de Estocolmo, Morandi (direcção), Rossacher (produção) - EuroArts

- Neblett, Domingo, Carroli; Royal Opera, Covent Garden, Santi (direcção), Faggioni (produção) - Warner Classics

- Daniels, Domingo, Milnes; Metropolitan Opera, Slatkin (direcção), del Monaco (produção) - Deutsche Grammophon

- Westbroek, Todorovich, Gallo; Netherlands Opera, Rizzi (direcção), Lehnhoff (produção) - Opus Arte

\section{AgradeCIMENTOS}

Gostaria de agradecer a todos os que contribuíram para melhorar este artigo: Jorge Calado, Mário Nuno Berberan e Santos, Raquel Gonçalves Maia, Frederico Lourenço e Ana Paula Esteves. Estou igualmente grato às seguintes entidades pela cedência de fotos: The Metropolitan Opera Archives, Metropolitan Opera e Opernhaus Zurich.

\section{REFERÊNCIAS}

[1] http://www.gutenberg.org/files/16551/16551-h/16551-h.htm (acedido a 11-06-2014) 
[2] http://www.princeton.edu/ achaney/tmve/wiki100k/docs/ John_Sutter.html (acedido a 11-06-2014)

[3] A. Jacobs, S. Sadie, "The Wordsworth Book of Opera", Wordsworth Editions, Ware, 1996

[4] C. Osborne, “The Complete Operas of Puccini”, Victor Gollanz, Londres, 1981

[5] M. Moreau, "O Teatro de S. Carlos - Dois Séculos de História”, Vol. 1, Hugin, Lisboa, 1999

[6] J.P. André, J. Chem. Educ. 90 (2013) 352-357

[7] Buffon, "Oeuvres Complètes”, Tomo 10, Garnier Frères, Paris, 1854

[8] C.R. Hayward, J. Chem. Educ. (1943) 29-32

[9] A.H. "Hiorns, Principles of Metallurgy", Forgotten Books, Londres, 2012

[10] A. Ramage, P. Craddock, "King Croesus Gold”, British Museum Press, Londres, 2000

[11] http://mygeologypage.ucdavis.edu/cowen/ GEL115/115ch6. html (acedido a 11-06-2014)

[12] E. Hamilton, "Mythology - Timeless Tales of Gods and Heroes”, Grand Central Publishing, Nova Iorque, 2011

[13] J. Emsley, “The Elements of Murder - A History of Poison”, Oxford University Press, Nova Iorque, 2005

[14] http://www.imazon.org.br/publicacoes/serie-amazonia/impactos-da-garimpagem-de-ouro-na-amazonia-oriental (acedido a 26-06-2014)

[15] P. Pyykkö, Annu. Rev. Phys. Chem. 63 (2012) 45-64

[16] N. Bartlett, Gold Bull. 31 (1998) 22-25

[17] A.H. Guerrero, H.J. Fasoli, J.L. Costa, J. Chem. Educ. 76 (1999) 200

[18] http://www.nma.org/pdf/gold/gold_history.pdf (acedido a 11-06-2014)

[19] C.D. Mickey, J. Chem. Educ. 58 (1981) 315-320

[20] http://www.nma.org/pdf/gold/gold_history.pdf (acedido a 11-06-2014)

[21] http://www.rsc.org/Education/EiC/issues/2008November/ TheElements.asp (acedido a 11-06-2014)

[22] http://www.bbc.com/news/magazine-21969100 (acedido a 11-06-2014)

[23] J. Calado, Química (Boletim da SPQ) 82 (2001) 31-30

[24] A.L. Lavoisier, “Tratado Elementar de Química”, Tomo I, Cap. XIII, Sociedade Portuguesa de Química, Lisboa, 2011

[25] M.T. De Saussure, Annales de Chimie 89 (1814) 273-305

[26] http://web.lemoyne.edu/ giunta/couper/couper.html (acedido a 11-06-2014)

[27] http://mattson.creighton.edu/SodaWater/SodaWater.html (acedido a 11-06-2014)

[28] A.J. Ihde, “The Development of Modern Chemistry”, Harper \& Row, Nova Iorque, 1964

[29] I. Gately, "Drink - A Cultural History of Alcohol”, Gotham Books, Nova Iorque, 2008
[30] S. Houlihan, J. H. Wotiz, J.Chem. Educ. 52 (1975) 362-364

[31] M.H.R. Beltran, Quím. Nova 4 (1996) 24-27

[32] R.J. Forbes, “A Short History of the Art of Distillation”, White Mule Press, 2009

[33] http://archive.nlm.nih.gov/proj/ttp/flash/brunschwig/brunschwig.html (acedido a 11-06-2014)

[34] D. Campbell, "Arabian Medicine and its Influence on the Middle Ages”, vol. 1, Routledge, Nova Iorque, 1926

[35] T. McKenna, "Food of the Gods", Bantam, Nova Iorque, 1992

[36] H. McGee, "On Food and Cooking: The Science and Lore of the Kitchen”, Scribner, Nova Iorque, 1984

[37] http://www.gutenberg.org/files/23280/23280-h/23280-h.htm (acedido a 11-06-2014)

[38] http://www.chemistryviews.org/details/ezine/1076111/ Chemistry_of_a_Hangover__Alcohol_and_its_Consequences_Part_2.html (acedido a 21-07- 2014)

[39] W. Shakespeare, “Macbeth”, Relógio de Água, Lisboa, 2006

[40] R. Marchese-Ragona, G. Marioni, A. Staffieri, Laryngoscope 114 (2004) 911-914

[41] L. Hutcheon, M. Hutcheon; “Opera, Desire, Disease, Death”, University of Nebraska Press, Lincoln, 1996

[42] C.K. Kokate, A.P. Purohit, S.B. Gokhale, "Pharmacognosy”, Nirali Prakashan, Pune, 2008

[43] P. Le Couter, J. Burreson, “Napoleon’s Buttons - 17 Molecules that Changed History”, Tarcher/Penguin, Nova Iorque, 2003

[44] A. Proença da Cunha, "Farmacognosia e Fitoquímica”, Fundação Calouste Gulbenkian, Lisboa, 2009

[45] M.M.M. Pinto, Química (Boletim da SPQ) 129 (2013) 25-32

[46] J.C.G. Calado, Química (Boletim da SPQ) 60 (1996) 26-32

[47] J. Calado, "Haja Luz - Uma História da Química Através de Tudo”, IST Press, Lisboa, 2011

[48] E.W. Ainscough, A. M. Brodie, J. Chem. Educ. 72 (1995) 686-692

[49] A.T. Balaban, W. Seitz, J. Chem. Educ. 80 (2003) 662-664

[50] A.J. Gow, Proc. Am. Thorac. Soc. 3 (2006) 150-152

[51] M.M.M. Pinto, “Química do Amor e do Sexo”, Lidel, Lisboa, 2010

[52] F.S. Gragasin, E.D. Michelakis, A. Hogan, R. Moudgil, K. Hashimoto, X. Wu, S. Bonnet, A. Haromy, S.L. Archer, The FASEB Journal 18 (2004) 1382-1391

[53] http://www.nobelprize.org/nobel_prizes/medicine/laureates/1998/ (acedido a 11-06-2014)

[54] http://www.theguardian.com/music/2003/mar/12/classicalmusicandopera.artsfeatures (acedido a 11-06-2014)

[55] http://metoperafamily.org/en/education/hd-live-in-schools/ School-Theater-Locations/ (acedido a 11-06-2014)

[56] http://www.metoperafamily.org/metopera/about/education/ educatorguides/content.aspx?customid=14592 (acedido a 11-06-2014) 